\title{
Primeiro relato no Brasil de mastite necrótica bovina por Clostridium perfringens tipo A
}

\author{
First report in Brazil of bovine necrotic mastitis due to Clostridium perfringens type $A$
}

\author{
Luciana Aramuni Gonçalves $^{1}$ Theonys Diógenes de Freitas $^{1}$ \\ Ronnie Antunes de Assis ${ }^{2}$ Elias Jorge Facury Filho ${ }^{3}$ \\ Francisco Carlos Faria Lobato ${ }^{4}$
} \begin{abstract}
Relata-se o primeiro caso no Brasil de mastite
bovina por Clostridium perfringens tipo A. O quadro clínico
caracterizou-se por necrose da papila mamária e porção ventral
do quarto afetado. O agente foi isolado em cultura pura e
identificado como tipo A por PCR a partir do leite do quarto
mamário afetado. RESUMO

Palavras-chave: Clostridium perfringens tipo A, mastite necrótica, bovino.

\section{ABSTRACT}

This report describes a case of bovine mastitis due to Clostridium perfringens type A for first time in Brazil. The unical case showed necrosis of papilla mammary and ventral portion of the affected quarter. The microorganism was isolated in pure culture and identified as type A by PCR from milk of the affected mammary quarter.
\end{abstract}

Key words: Clostridium perfringens type A, necrotic mastitis, bovine.

A mastite necrótica causada por $\boldsymbol{C}$. perfringens tipo A caracteriza-se pela contaminação do canal galactogênico pela, hipertermia da glândula e pela necrose do parênquima mamário, acompanhadas de fluxo hemorrágico e fétido (BEER \& ALKHATIB, 1968). Tal processo é decorrente da toxina alfa e de outros antígenos menores secretados pelo agente na glândula mamária. Além da lise de eritrócitos, as toxinas lisam plaquetas e leucócitos, causando liberação de histamina, agregação plaquetária ao longo da parede dos vasos e vênulas com posterior formação de trombos (FLORES-DIAZ \& ALAPE-GIRON, 2003). Na maioria das vezes, a mastite necrótica causa perda do quarto mamário afetado, porém, quando ocorre toxemia, o animal pode vir a óbito.

Este trabalho relata pela primeira vez no Brasil um caso de mastite necrótica bovina por $\boldsymbol{C}$. perfringens tipo A. Segundo relato do veterinário local, no período entre outubro e dezembro de 2004, ocorreram em uma propriedade de exploração leiteira intensiva, em Ilicínea, Minas Gerais, Brasil, três casos de mastite com aspecto necrosante, envolvendo vacas 3/4 holandês de primeira e segunda lactação, sendo que duas estavam recém-paridas e a terceira no pré-parto.

\footnotetext{
${ }^{1}$ Programa de Pós-graduação em Medicina Veterinária Preventiva, Escola de Veterinária da Universidade Federal de Minas Gerais (UFMG), Belo Horizonte, MG, Brasil.

${ }^{2}$ Laboratório de Anaeróbios, Departamento de Medicina Veterinária Preventiva da Escola de Veterinária da UFMG, Belo Horizonte, MG, Brasil.

${ }^{3}$ Departamento de Clínica e Cirurgia Veterinária, Escola de Veterinária da UFMG, Belo Horizonte, MG, Brasil.

${ }^{4}$ Departamento de Medicina Veterinária Preventiva, Escola de Veterinária da UFMG, Av. Antônio Carlos, 6627, CP 567, Campus da UFMG, 30123-970, Belo Horizonte, MG, Brasil. E-mail: flobato@vet.ufmg.br.
} 
Durante o período pré-parto, os animais eram mantidos em piquete e alimentados com silagem de milho, dois kg de ração comercial de pré-parto, suplemento mineral e água à vontade. Após o parto, eram transferidos para o confinamento em sistema de “free stall”. A condição higiênica do piquetematernidade era inadequada, com acúmulo de matéria orgânica ao redor dos cochos, devido à abundância de chuvas no período. Nesta propriedade, a vacinação contra clostridioses era realizada apenas em bezerros aos quatro meses de idade, com vacinas polivalentes.

Amostra de leite para diagnóstico laboratorial foi colhida apenas da terceira vaca. Esse animal apresentou inicialmente apatia, diminuição do consumo de alimento e hipertermia. No segundo dia, o animal foi examinado pelo veterinário, que observou aumento de volume do quarto posterior esquerdo, cujas papila mamária e porção ventral apresentaram diminuição de temperatura, coloração arroxeada e presença de secreção espessa e amarelada. Não foi evidenciada a ocorrência de crepitação na região. No dia seguinte, houve uma evolução do quadro, culminando com necrose e queda da papila mamária. Foi realizado tratamento parenteral com penicilina, na dose de $20000 \mathrm{UI} \mathrm{kg}{ }^{-1}$ de peso vivo (pv), associado com enrofloxacina (2,5 $\mathrm{mg} \mathrm{kg}^{-1} \mathrm{de} \mathrm{pv}$ ), por três dias. $\mathrm{O}$ animal mostrou recuperação sistêmica após o tratamento, com perda funcional e anatômica da papila afetada.

Amostra da secreção da papila afetada foi colhida assepticamente em frasco estéril antes do início do tratamento e enviada em refrigeração para o Laboratório de Anaeróbios da Escola de Veterinária da UFMG, para exames bacteriológicos. Alíquota desse material foi assepticamente diluída em $0,5 \mathrm{ml}$ de solução salina estéril a 0,85\%. Esfregaços foram confeccionados e corados pelo Gram. Alíquotas adicionais foram semeadas em ágar sangue e incubadas em atmosferas de aerobiose e anaerobiose a $37^{\circ} \mathrm{C}$, por 48 horas. Crescimento ocorreu somente em anaerobiose, caracterizado apenas por colônias com um duplo halo de hemólise e aspecto umbilicado, sugestivas de $\boldsymbol{C}$. perfringens. Colônias foram submetidas às seguintes provas bioquímicas: fermentação da glicose, lactose, sacarose e maltose, atividade enzimática da lecitinase e lipase, hidrólise da gelatina, digestão de caseína e produção de indol (QUINN et al., 1994). Foram também examinadas por uma técnica de PCR, segundo UZAL et al. (1997), utilizando-se os seguintes iniciadores para detecção dos genes codificadores da toxina alfa: senso 5'TGCTAATGTTACTGCCGTTGATAG-3' e anti-senso 5'-ATAATCССАATCATCCCAАСТATC-3'; beta, senso 5'-AGGAGGTTTTTTTATGAAG-3' e anti-senso 5'-TCTAAATAGCTGTTACTTTGT-3'; épsilon, senso 5'-TACTCATACTGTGGGAACTTCGATACAAGC-3'e anti-senso:

5'-CTCATCTCCСATAACTGCACTATAATTTCC-3'; iota, senso 5'-TTTTAACTAGTTCATTTCCTAGTTA3' e anti-senso 5' TTTTTGTATTCTTTTTCTCTAGATT-3’.

À bacterioscopia, observou-se presença abundante de bastonetes Gram positivos curtos, grossos, não esporulados, sugerindo tratar-se de $\boldsymbol{C}$. perfringens. Por meio dos testes bioquímicos, as colônias foram classificadas como $C$. perfringens e, pela PCR, foram tipificadas como $C$. perfringens tipo A, amplificando somente o fragmento de 247pb correspondente ao gene codificador da toxina alfa.

Com base nos achados clínicos e microbiológicos, permitiu-se firmar o diagnóstico de mastite necrótica bovina por $\boldsymbol{C}$. perfringens tipo A.

Apesar da maioria das mastites bacterianas serem causadas por bactérias aeróbias (COSTA et al., 1986), é crescente a preocupação do envolvimento de agentes anaeróbios nesses processos patológicos (DU PREEZ, 1989). Segundo esse autor, a principal razão para o número limitado de trabalhos relatados sobre o envolvimento de bactérias anaeróbias deve-se à dificuldade para o cultivo desses microrganismos.

Casos de mastite gangrenosa por $\boldsymbol{C}$. perfringens tipo A foram relatados em vários países (RENK, 1967; GIESECKE et al., 1969; GUSTAFSON, 1977). No Brasil, BALDASSI et al. (1995) relataram a ocorrência de quatro casos de mastite gangrenosa bovina causados por Clostridium sordellii, Clostridium septicum e Clostridium butyricum, constituindo-se, até então, no único trabalho existente no Brasil sobre tal afecção. Portanto, o presente trabalho constitui o primeiro relato de mastite necrótica por $\boldsymbol{C}$. perfringens tipo A em bovinos no Brasil.

C. perfringens tipo A é freqüentemente isolado em fezes de animais sadios (NIILO, 1980). No presente caso, a grande contaminação ambiental, favorecida pelas condições climáticas e pelo acúmulo de matéria orgânica no piquete-maternidade, propiciaram a contaminação ascendente da papila mamária por $\boldsymbol{C}$. perfringens tipo A. Além disso, no préparto, as vacas apresentam queda da imunidade, em decorrência da colostrogênese e da liberação de corticóides endógenos (MALLARD et al., 1998). Esses fatores favoreceram a contaminação e instalação do processo infeccioso. Portanto, cuidados relacionados às condições ambientais devem ser adotados para prevenção da mastite necrótica por $\boldsymbol{C}$. perfringens tipo A. 


\section{AGRADECIMENTO}

Os autores agradecem ao Dr. Evandro Vilela Ribeiro pelo envio da amostra de leite do animal afetado.

\section{REFERÊNCIAS}

BALDASSI, L. et al. Mastite gangrenosa bovina causada por agentes do gênero Clostridium. Arq Inst Biol, v.62, p.15-20, 1995.

BEER, J.; AL-KHATIB, G. Zum nachveis und zur differenzierung pathogener Clostridien und ihrer toxine. Mh Vet Med, v.23, p.709-714, 1968

COSTA, E.D. et al. Etiologia da mastite ovina no Estado de São Paulo. Rev Microbiol, v.17, p.107-112, 1986.

DU PREEZ, J.H. The role of anaerobic bacteria in bovine mastitis: a review. J South Afr Vet Assoc, v.60, p.159-168, 1989.

FLORES-DIAS, M.; ALAPE-GIRON, A. Role of Clostridium perfringens phospolipase $\mathrm{C}$ in the pathogenesis of gas gangrene. Toxicon, v.42, p.979-986, 2003.
GIESECKE, W.H., et al. Bovine mastitis due to Clostridium perfringens type A and Bacillus cereus. J South Afr Vet Assoc, v.40, p.342, 1969.

GUSTAFSON, D.P. Report of the panel of the colloqium on bovine mastitis. J Am Vet Med Assoc, v.170, p.1119-1123, 1977.

MALLARD, B.A., et al. Alteration in immune responsiveness during the peripartum period and its ramification on dairy cow na calf health. J Dairy Sci, v.81, p.585-595, 1998.

NIILO, L. Clostridium perfringens in animal disease: a review of current knowledge. Can Vet J, v.21, p.141-148, 1980.

QUINN, P.J. et al. Clostridium species. In: Clinical Veterinary Microbiology. Elsevier: London, 1994. p.191208.

RENK, W. Etiology, pathogenesis and morphology of bovine mastitis. Vet Med Review (Bayer), v.1, p.1-21, 1967.

UZAL, F.A. et al. PCR detection of Clostridium perfringens producing different toxins in faeces of goats. Lett Appl Microbiol, v.25, p.339-344, 1997. 